\title{
The Cinema Context Database on Film Exhibition and Distribution in the Netherlands: A Critical Guide
}

\author{
Arts and Media
}

\author{
Thunnis van Oort \\ Universiteit van Amsterdam, Amsterdam, Netherlands \\ t.vanoort@uva.nl \\ Julia Noordegraaf \\ Universiteit van Amsterdam, Amsterdam, Netherlands \\ j.j.noordegraaf@uva.nl
}

\begin{abstract}
Cinema Context is an online database for researching the history of cinema exhibition and distribution in the Netherlands. It contains structured information on venues, persons and companies involved in the dissemination of film from the late nineteenth century until the present day, with an emphasis on the first half of the twentieth century. Aim of this paper is to document and critically reflect on the creation of the database and account for and motivate the choices made in constructing the data model and collecting the data.
\end{abstract}

\section{Keywords}

cinema history - film exhibition - digital databases - data models

- Related data set "Cinema Context. Film in Nederland vanaf 1896: een encyclopedie van de filmcultuur" with DoI https://www.doi.org/10.17026/dans -z9y-c5g6 in repository "DANs"

- See the showcase of the data in the Exhibit of Datasets: https://www.dans datajournal.nl/rdp/exhibit.html? showcase=0ort2020a 


\section{Background}

Cinema Context is an online database for researching the history of cinema exhibition and distribution in the Netherlands, covering a period from the late nineteenth century until the present (http://www.cinemacontext.nl/). Since its official launch in 2006, the database has been continuously edited and extended with new data, initially by Karel Dibbets and, after his death in 2017, by an editorial office at the University of Amsterdam's Centre for Cultural Heritage and Identity (ACHI). ${ }^{1}$ This data paper provides a detailed description of the database, outlining the choices made in collecting and organizing the data and the implications of these choices for using the database in film historical research. The paper aims to increase the transparency of Cinema Context and thus contributes to its usability as an instrument for scholarly research.

Cinema Context is both the result and catalyst of a broader movement in historical film studies known as 'New Cinema History', which focuses on moviegoing as a social and cultural phenomenon, rather than on films as aesthetic objects (Biltereyst, Maltby, \& Meers, 2011). Collecting information on the 'Who, What, Where and When of film exhibition and distribution', in the words of Dibbets, allows scholars to study 'the DNA of film culture' (Dibbets, 2010, p. 331). Cinema Context is both used as a straightforward encyclopaedia for looking up facts and for more complex analyses of patterns and networks in film distribution and exhibition (Noordegraaf, Lotze, \& Boter, 2018).

The international community of experts in the field of film and cinema history regards Cinema Context as a standard that has served as an example for similar databases around the world (see, for example, Abbott, 2010; Allen, 2010; van Asseldonk, et al., 2009; van Oort \& Pafort-Overduin, 2018). Cinema Context has been praised internationally as 'unique in the world' (Garncarz, 2015, p. 201) and 'the finest film reference source on the Web, for all film let alone silent film' (McKernan, 2017).

\subsection{Origins of the Database}

The Cinema Context database was created by the historian and film scholar Karel Dibbets (1947-2017). The first component of the data collection dates back to Dibbets' work on chain formation in the Dutch market for cinema

1 The editorial office currently consists of editor-in-chief Julia Noordegraaf, editor Thunnis van Oort and programmer Ivan Kisjes, and is located in the CREATE program at the Amsterdam Centre for Cultural Heritage and Identity (http://www.create.humanities.uva.nl/). For this article, a snapshot (December 2018) of the dataset has been stored at DANs: https://doi. org/10.17026/dans-z9y-c5g6. Detailed documentation of the various fields in the database is included there. 


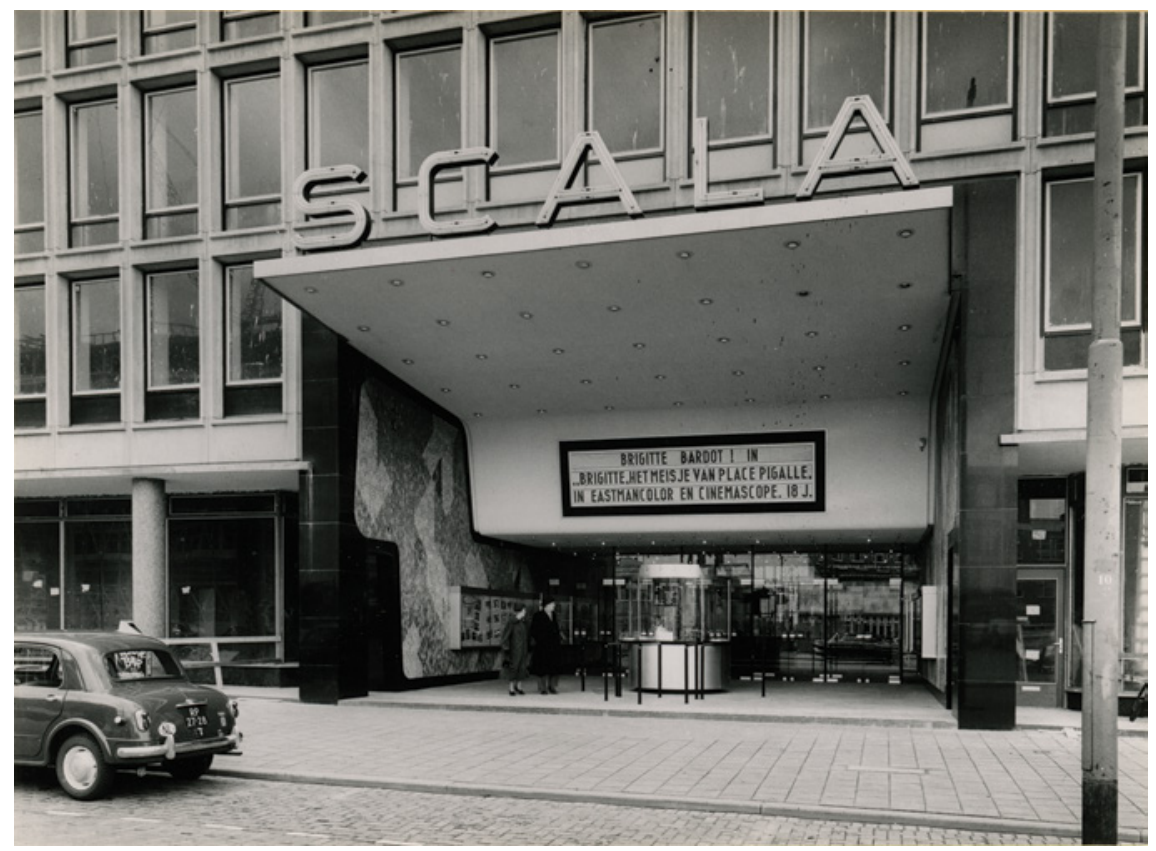

FIGURE 1 Scala Cinema in Rotterdam, 1957-1958. Stadsarchief Rotterdam.

exhibition between 1928 and 1977 , for which he collected data on cinemas and their managers and owners from the membership lists of the Dutch branch organisation Nederlandse Bioscoopbond (Dibbets, 1980). Supported by the then-new method of network analysis, newly developed software and access to the one supercomputer available at the University of Amsterdam in 1979, Dibbets' analysis demonstrated a gradual concentration of cinema ownership in so-called chains that came to dominate the cinema market in the post-WWII period, in particular in the three largest cities of Amsterdam, Rotterdam and The Hague. The legacy of this research was an extensive dataset listing cinemas, their locations, the people and companies involved in running cinemas, as well as distribution companies and the people behind them. This dataset forms the core of the Cinema Context dataset, that has been supplemented and improved upon by Dibbets in the following decades.

In the 1990s, the data were available online (Dibbets, 2010, p. 334). In 2003, the Dutch Research Council Nwo granted a large infrastructure subsidy to greatly expand the existing dataset and build the digital infrastructure to store the data and publish them online. The development of the data model and the implementation of the required software was realized by the Digital Production Centre (DPC) of the Library of the University of Amsterdam. In the 


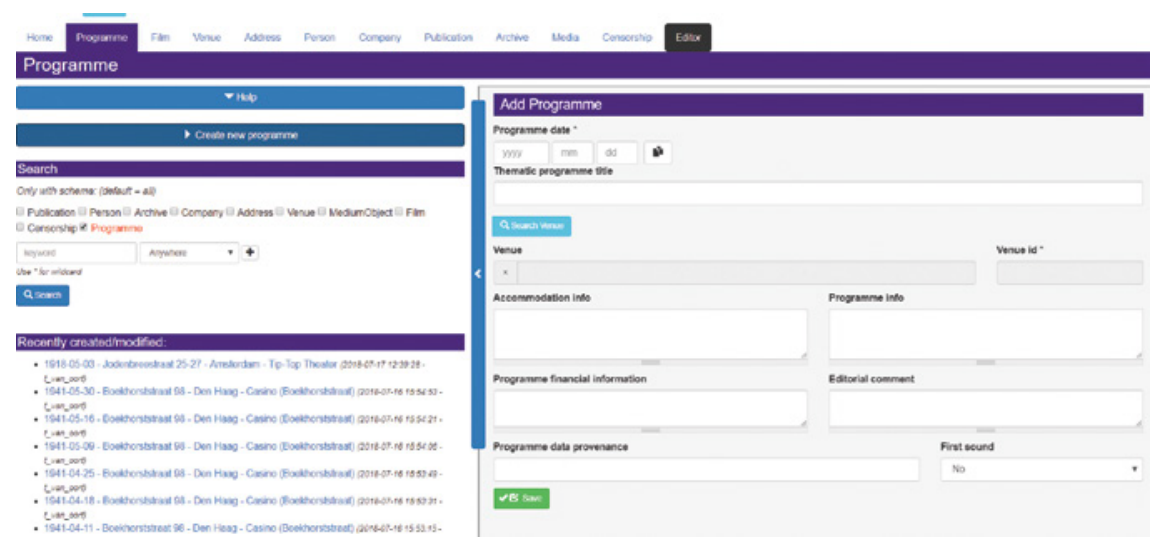

FIGURE 2 Screenshot of the Cinema Context Editor

framework of this project, collections of film titles, film censorship records and film programmes (data on specific films screened at a certain time and place, collected from advertisements in contemporary newspapers) were added.

Before his death in May 2017, Karel Dibbets transferred the ownership and curation of Cinema Context to the digital humanities research programme CREATE at the University of Amsterdam. In his final years, he was still actively involved in the design of the most recent extension to Cinema Context, the Cinema Context Editor, an interface developed by the DPC that facilitates adding and correcting new data (Fig. 2). The editorial team, headed by editorin-chief Julia Noordegraaf, is currently implementing the new editor and planning further extensions of the dataset and the functionality of the website. ${ }^{2}$

\section{Data Model}

- Cinema Context. Film in Nederland vanaf 1896: een encyclopedie van de filmcultuur

- Public interface - URL: http://www.cinemacontext.nl/

- Snapshot deposited at DANS - DoI:https://www.doi.org/10.17026/dans -z9y-c5g6

- Temporal coverage: 1896-2018, continuing

2 During the period when this article was being prepared for publication, a "Small data project" grant was awarded by DANs that allows for the conversion of the Cinema Context dataset into RDF and make it available as Linked Open Data in 2020. The result is available here: https://www.gitlab.com/uvacreate/cinema-context/cinema-context-rdf. 
Cinema Context is a relational database, meaning that each table consists of records with unique identifiers that allow linking a record to records in the various other tables. Ten tables form the core of the database; the other 53 tables are either subcategories or 'join' tables. Below we describe the most significant tables. For a more detailed description of tables and fields, please consult the more extensive documentation that accompanies the deposited database.

Programme (tblProgramme) - A programme consists of a combination of a date, a venue - usually a (travelling) cinema theatre - and one or more 'programme items', which are usually film titles.

Film (tblFilm) - This table stores film titles, taken from a variety of historical sources, such as newspapers, trade papers and the Desmet business archives (archived at EYE Film Institute). Cinema Context does not systematically collect productional information on the films, such as actors, genre, et cetera. This type of data is available in other online databases, of which the Internet Movie Database (IмDв: https://www.imdb.com/) is the most comprehensive. (Chew \& Elhard, 2005) Where possible, Cinema Context provides a link to the unique IMDB ID for each identified film title.

Venue (tb/Venue) - This table stores data on the cinema theatres. Its title can be somewhat misleading, because the table does not capture information about the buildings where films were screened but refers to a cinema operation that was active at a certain period, run by a specific person or company. This distinction was necessary to accommodate the phenomenon of travelling cinema in the data model, that did not necessarily operate in buildings but also in tents and other ambulant structures.

Address (tblAddress) - This table stores the addresses of the cinema venues and their geolocation. In some cases it contains a link to information on the buildings located at these addresses (tblAddressConstructionHistory).

Person (tblPerson) and Company (tblCompany) - These tables store natural persons and legal entities.

Publication (tblPublication) and Archive (tblArchive) - The Publication and Archive tables provide the source references for the information contained in the database (respectively bibliographical information and unpublished sources).

Censorship (tblCensorship) - The Censorship table contains records of the national censorship board. The board's permit was required for all publicly screened films in the Netherlands between 1928 and 1977. Its archival records contain useful information such as the original movie titles and (translated) titles used for the release on the Dutch market, the name of the distributor and the censorship classification. 


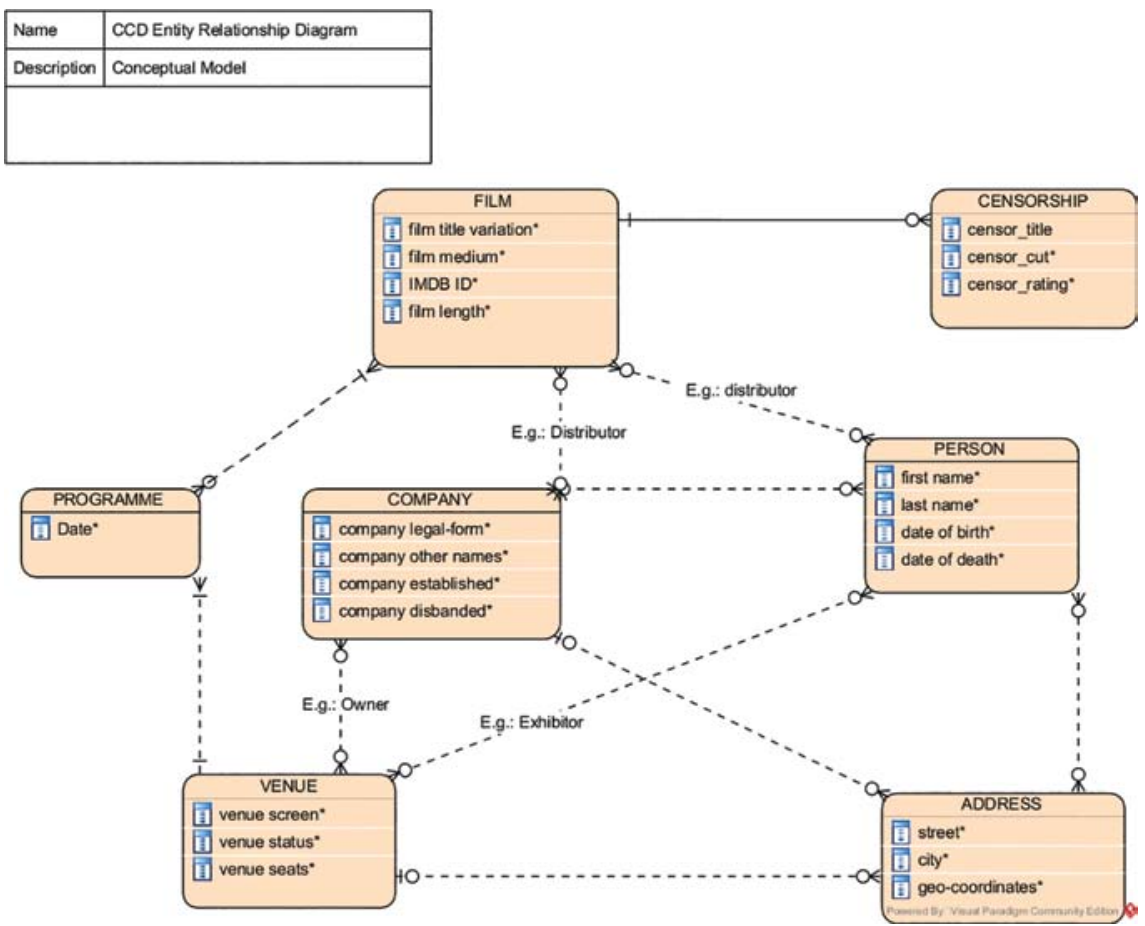

FIGURE 3 Conceptual Entity Relationship Diagram of the Cinema Context data model. This is not a mapping of all the tables and fields; more precise technical diagrams can be found in the documentation at the EAsY repository. For the sake of clarity, some entities and entity relations have been left out. For instance, to prevent a cluttered cloud of connections, the Publications, Archive and Medium tables have been omitted here. These entities are potentially connected to virtually all other main entities, functioning as references to sources or images. Also, some connections that do exist in the database have been omitted from the diagram, again, for clarity's sake. For example, the censorship entity is connected to the company entity, because the censorship organisation is listed as a legal entity in the company table.

Media (tblMediumObject) - Cinema Context does not hold digital media objects, but, where possible, provides links to digital media objects stored in other locations.

\section{Data Collection}

For much of the information stored in Cinema Context, source references are available, but not every single data point can be attributed to a specific source. 
To understand which parts of the data collection come from which sources, it is necessary to describe the data collection process in more detail.

The core of the dataset on cinemas, persons and companies was collected via the name and address lists of the trade organisation NBB (Nederlandse Bioscoopbond, Netherlands Cinema League; see Figure 4). Since the mid-1920s it was not possible to run a commercial cinema in the Netherlands without membership of the NBB, which makes its archive an uncommonly complete historical source for cinemas (and distributors) in the Netherlands (van der Velden, van Oort, \& de Jong, 2013; van Oort, 2018). The cinemas in the period before the mid-1920s, including travelling cinemas, have been collected from a variety of sources such as newspapers and trade papers (see Figures 4 and 5). Over the years, cinemas, persons and companies have been added to the data collection.

The bulk of the film programming information (which films were screened at which cinema at which date) was manually copied from weekly newspaper listings and advertisements. ${ }^{3}$ Table 1 presents an overview of the newspapers that were used by the data entry team to document the weekly film programmes in several Dutch cities in the period 1896-1948. The most comprehensive series of programming data has been collected for the following cities: Amsterdam, Rotterdam, The Hague, and Utrecht, Leiden and Groningen.

The longitudinal series of programming data for these six cities has been supplemented with smaller portions of programming data for other municipalities, by adding data sets collected by researchers and students. The most important of these 'data donors' are currently mentioned on the Cinema Context website's colophon (Cobi Bordewijk, Rudmer Canjels, Jan Hein Furnée, Clara Pafort-Overduin, Aafje Terwey, Frans Westra).

The obvious advantage of these additions is a broader and more detailed and diverse dataset that includes cinema programming in smaller cities and towns. The researcher using the data set, however, should be aware of the fact that for some periods or geographic areas the data set is more complete than for other periods or places and this can have effects on the representativeness of the data. For instance, if a researcher wants to do a comparative or longitudinal analysis of film programming in the $1920 \mathrm{~s}$ and 1930s, (s) he should be aware that programming data for the period 1934-1935 covers a much wider geography than in other years, because of the dataset donated by

3 The guidelines that were used by the editorial team that entered and modified data, especially programming data, in the Cinema Context database, is available at https://www.doi .org/10.21942/uva.7398812. 


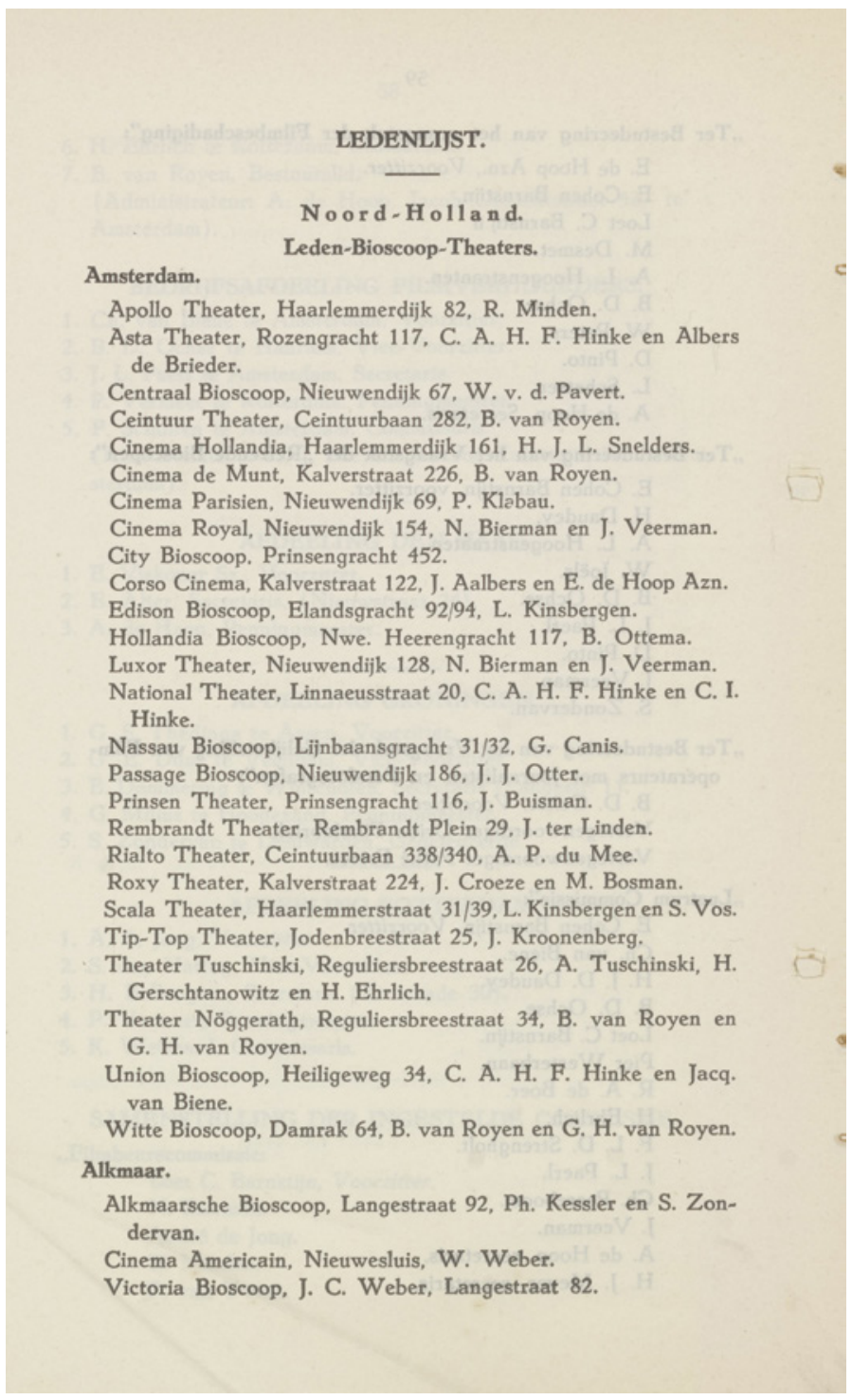

FIGURE 4 First page of the membership list of trade organisation NBB. Annual report 1927. FROM HTTP://FILM-BIOSCOOPBRANCHE.NL/ISSUE/JRV/1927-01-01/EDITION/ NULL/PAGE/61.

Clara Pafort-Overduin, that includes film programming in several small towns in the South of the Netherlands. Figure 6 shows for which cities in which years programming data is currently available in the database. In general, the coverage is optimal for the 6 cities mentioned earlier (Amsterdam, Rotterdam, The 
Voor de zooveelste maal is de Wester-Bioscoop op het Haarlemmerplein in exploitatie gebracht.

Hedenavond heropent eenigszins feestelijk de Cinema De Munt* in de Kalverstraat.

Binnen zeer korten tijd heeft men in dit theater verschillende veranderingen aangebracht, alles schoongemaakt en opnieuw geschilderd, de licht- en kracht-installatic herzien en verbeterd, kortom, datgene gedaan wat noodzakelijk is om een theater van den eersten rang te doen zijn. Zooals men weet opent de Directie met een uitgezocht programma van de H. A.P. Film Co. te Den Haag. en zijn voor dezen avond speciale uitnoodigingen gezonden aan vakpers, confraters en belangstellenden. Volgende week hopen wij meer over deze opening mede te deelen.

Vanaf heden Vrijdag loopt in de Cenema Palace alhier de film „Het Ghetto ontvlucht“ (Glaubensketten), de tragedie der menschen, Joodsch probleemfilm van Erna Meinert. De groote roep van dit werk zal de belangstelling van velen opwekken en zullen wij de volgende week hiervan de verhandeling mededeclen.

ROTTERDAM, Kosmorama Bioscope. Naar wij vernemen zal dit theater over cenigen tijd verdwijnen en dan het pand eene andere bestemming krijgen.

Palace Bioscope. Er gaan geruchten dat ook dit theater binnenkort zal worden gesloten, om plaats te maken voor kantoorgebouwen.

Heel wat huizen worden op den Coolsingel voor kantoorbouw aangekocht, met het oog op het aldaar in aanbouw zijnde nieuwe Stadhuis en Postkantoor.

Alcazar Theater. Deze Bioscope is gedurende een week gesloten, om daarna door de Naamlooze Vennootschap, die vroeger het beheer over dit theater had, weder zelf te worden geëxploiteerd.
Scala Bioscope. Een bijzonder mooi hoofdnummer zagen wij hier afdrasien en wel .Arpad Szomory" de vioolvirtuoos, welke rol in het filmdrama "Het Wiegenlied" door den grooten Rudolf Schildkraut op meesterlijke wijze wordt gespeeld. Doch ook de overige medespelenden dienen geprezen om hunne uitstekende uitbeelding en goede opvatting van hun spel.

In het comische genre ging ,De Weduwe zonder kinderen".

Naar de explicatie van den heer Hartog hebben we met genoegen geluisterd, alsmede maken wij het orkest, onder aanvoering van den heer Borstlap, een compliment voor de correcte en passende muzikale illustratie van het geheel.

Olympia Bioscope. Deze zaak is reeds heden gesloten en de verbouwing in volle gang. Ongetwijfeld zal ook hier een theater verrijzen dat, wat inrichting en luxe betreft, kan wedijveren met de drie andere theaters van den heer Tuschinski. Heropening word later bekend gemaakt.

Cinéma Royal. Als hoofdnummer, „De Vliegende Hollander", een Nordisk-drama in 3 afdeelingen, waarin vele mooie momenten voorkomen. Vooral de ondergang van het oude schip wordt mooi weergegeven. Een tragicomédie van de "Reliance", getiteld "Boefje", is een één-Acter van fijne handeling, en „Het Geheim van de Aschbak" („Majestic*), een comedie van de serie Moderne kinderen. Een klucht in 2 Acten (_Luna"), „de Familie Prikkelman" voltooide het bioscopisch gedeelte, waarna Henriette Blazer ons met haar aardig nieuw repertoire verraste. De explicatie van den heer De Jong verdient alle lof, zoowel in het dramatische als in het komische genre. De begeleiding der films en artisten geschiedt door het orkest, onder leiding van den heer $\mathrm{Ch}$. Wallace, op uitnemende wijze.

FIgURE 5 Trade paper De Bioscoop-Courant featured news on cinema exhibitions around the country under the heading 'Van hier en elders' (From here and elsewhere), containing useful information about cinemas, persons and companies. For instance, in the 26 May 1916 issue it reports on: 'yet another' restart of the cinema operation Wester-Bioscoop and the reopening of cinema De Munt after a refurbishing in Amsterdam, about the Rotterdam market it announces the planned moving of Rotterdam cinema Kosmorama, mentions the limited company that runs the Alcazar Theatre and reports on the temporary closing for refurbishment of the Olympia cinema, run by exhibitor Tuschinski.

DELPHER (HTTPS://RESOLVER.KB.NL/RESOLVE?URN=MMEYE01:

000788036:00007).

Hague, and Utrecht, Leiden and Groningen) and is not representative of the Dutch market, as it is biased towards urban areas located in the western part of the country (Holland/'Randstad'). In the period until 1912, when travelling cinema is a dominant form of film exhibition, the coverage is more varied, as is clearly illustrated in Figure 6. 
TABLE 1 Newspapers used as the source for programming data for specific cities/regions (for 100 programmes or more). The NULL entry refers to programming data where no source was specified. The frequency refers to the number of references made to that newspaper as a source for a cinema programme

\begin{tabular}{lll} 
Frequency & Newspaper title & City \\
\hline 25382 & Haagsche Courant & The Hague \\
24857 & Rotterdamsch Nieuwsblad & Rotterdam/Schiedam \\
22814 & De Telegraaf & Amsterdam \\
7346 & Utrechtsch Nieuwsblad & Utrecht \\
6356 & Leidsch Dagblad & Leiden \\
6044 & Nieuwsbladvan het Noorden & Groningen \\
4060 & Het Parool & Amsterdam \\
1415 & Algemeen Handelsblad & Amsterdam \\
1277 & Limburger Koerier & Limburg province \\
1193 & Utrechtsch Provinciaal en Stedelijk Dagblad & Utrecht \\
1135 & Nieuws van de Dag & Amsterdam \\
931 & NULL & Various \\
696 & De Waarheid & Den Haag \\
220 & Dordrechtsche Courant & Dordrecht \\
206 & IJmuider Courant & IJmuiden \\
192 & Het Volk & Amsterdam \\
189 & Zierikzeesche Nieuwsbode & Zierikzee \\
152 & Zandvoortsche Courant & Zandvoort \\
134 & De Bussumsche Courant & Bussum \\
105 & Asmodée & Amsterdam \\
\hline & &
\end{tabular}

\section{Discussion}

This section discusses some aspects of the data collection and the design of the data model that merit critical reflection on the benefit for scholars that plan to use the data in their research.

\subsection{Data Collection}

A structural source of the Cinema Context data collection is the archives and publications of the trade organisation мвв. These records represent a quite systematic and representative collection of sources, but they nevertheless contain gaps and biases. Cinema Context has benefitted from the NBB's 

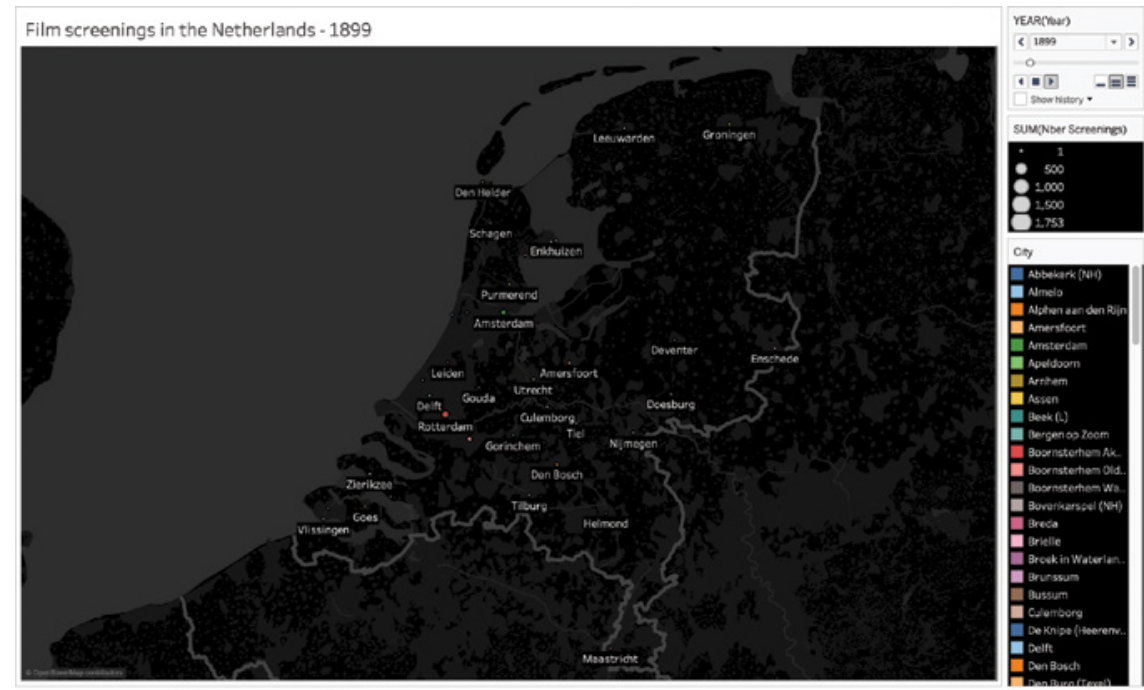

FIGURE 6 Still from a visualization that shows for which cities programming data is currently available in the Cinema Context database, per year. (See full visualization here.)

comprehensive membership administration that has provided the backbone of the datasets on cinemas, companies and persons. The degree of completeness of these NBB records is hard to match in other countries. For instance, in neighbouring Belgium, the absence of a central, overarching organisation for movie exhibitors has proven an obstacle for compiling reliable lists of cinemas, because competing trade publications provided contradictory accounts (Biltereyst \& de Potter, 2018; van Oort, 2017). Still, a critical evaluation of the sources is warranted. For instance, it has been pointed out that the sudden rise of cinema operations in the late 1920 s potentially did not reflect a real increase but rather was caused by a boost of NBB membership that brought into view cinemas that had already been in operation earlier but had not yet been registered (Thissen, van der Velden, \& van Oort, 2009).

Another issue that users of the Cinema Context data need to take into account, is the NBB's strong control over (and suppression of) film screenings outside of the commercial circuit. Without NBB membership, no one was allowed to rent or screen films, unless with explicit dispensation from the NBB strictly for non-commercial exhibition. ${ }^{4}$ Clubs and associations with such

4 The term non-commercial is not without complications, because some of these screenings outside of the regular cinemas could very well have had a commercial character. But this discussion would go beyond the scope of this paper. 
dispensation would only receive films under certain restrictions that would limit the competition to commercial exhibitors. For example, commercial advertisements were prohibited, which means these screenings left little traces in the press for the historian to recover. Information on these non-commercial film screenings and the venues where they took place is not systematically available and hence only incidentally included in Cinema Context. However, we know that certain social movements, such as Christian and Communist organizations (KFA, CEFA), actively organized film screenings for their membership. ${ }^{5}$ Presumably, non-commercial film exhibition comprised only a small fraction of the market, but because the data have not been systematically collected, the exact size of this part of Dutch cinema culture cannot be established.

\subsection{Data Model}

Over the past decades, compared to the fairly simple lists of persons, people and companies it started with, Cinema Context has developed into a relatively complex and fine-grained data model. Nevertheless, in some instances, the data model remains less detailed, for instance when describing persons, buildings or locations. ${ }^{6}$ This has been a deliberate choice by the designers of the model when weighing the advantages of a more detailed data model to the disadvantages that higher complexity would have for the ease of use and the investment cost involved in data collection and registration: entering over 100,000 film programmes would not have been achievable using a data model with the highest granularity.

The consequences of the degree of granularity can be observed in the modelling of the film screening event, for which the elementary unit of information is the date (day) of screening. In practice, however, it is not the day but the week that counts as the basic temporal unit, at least for the largest part of the period that is covered by the data set. In the Dutch film distribution system the change of programme was - and still is - predominantly weekly.

5 This research has been carried out by Jolanda Visser in the context of the CINEMAPS project at CREATE, see http://www.create.humanities.uva.nl/results/cinemaps-a-datadriven-investigation-of-cinema-markets-in-the-netherlands-and-flanders-1950-1975/, and Noordegraaf et al., 2017.

6 At the time when the data model was designed, the choice was made to keep the Address table relatively simple because buildings and architectural history are not the main focus of Cinema Context. Ideally, this table could be split into separate tables for addresses and geolocation, perhaps even adding a third table for buildings as well, in order to improve the opportunity for linking to other geodata, for instance on buildings ('kadaster'). We encountered this complication during a Linked Open Data pilot with Menno den Engelse and his 'Lost Buildings' project, see http://www.verdwenengebouwen.nl/thema/6. 
This is reflected in the data model because only the weekly starting date of the cinema programme is registered (usually a Friday). In cases where a screening deviates from this weekly pattern, the irregularities are mentioned in an explanatory text field. Examples include films with unique or limited screenings during the week such as Sunday children matinees, or programming in cinemas that would only screen for two or three days per week (common for cinemas in more rural areas). Consequently, analyses of the programming data would have to exclude or correct for these irregular screenings to obtain a representative overview. This is particularly relevant when exploiting Cinema Context's potential for researching cinema attendance.

Confronted with the absence of box office statistics before the 1970s, the number of weeks that a specific film title has been screened can serve as a relative measure of its popularity. For example, based on the Cinema Context programming data, Karel Dibbets found that the top ten of films with the highest number of screening weeks in the large cities in the period up until the Second World War contains four Dutch films, including ranking positions 1 and 2, respectively De Jantjes (1934) and Pygmalion (1937). This demonstrates that Dutch audiences preferred a national product, even if only a tiny fraction of the film supply was domestic (see also Pafort-Overduin, 2012). Furthermore, only three titles in this pre-war top ten were American-made, which complicates the notion of Hollywood market dominance and, thus, shows the potential of data-driven cinema historical research for revisiting existing assumptions about local film cultures (Dibbets, 2010, p. 341; see also Garncarz, 2015).

Statistics based on the number of playing weeks, thus, can provide insight into the preferences of historical film audiences. But the lack of precision in the data model can also present problems for use of the programming data in film historical research. First of all, the Dutch distribution arrangement of weekly programme changes is not necessarily representative of other markets. For instance, in Italy and Great Britain, several programme changes per week occur, even daily changes are common in some cases (Gennari \& Sedgwick, 2015; Sedgwick, 2000). As such, the focus on the week as a temporal unit for programmes can complicate transnational comparisons. More fundamental issues arise when scholars want to perform statistical analyses on the programming data. An example is the application of the POPSTAT method that has been developed by John Sedgwick to measure the popularity of films in the absence of box office information (Sedgwick, 200o). ${ }^{7}$ To calculate this index, the number of individual screenings per week is preferred. But in the Cinema

7 For an example of an application of the POPSTAT method on data retrieved from Cinema Context, see Sedgwick, Pafort-Overduin, \& Boter, 2012. 
Context data set, a film with one single matinee screening would have the same weight as a film that would normally be screened perhaps five times a day, seven days a week.

We have encountered this complication during a pilot study, comparing film programming during the Second World War in Amsterdam and The Hague (data from Cinema Context) and Antwerp (a data collection assembled by Roel Vande Winkel) (van Oort, Kisjes, \& Vande Winkel, 2018). Using a simplified derivative of the POPSTAT method, we ranked titles by a measure of their popularity, based on the number of weeks they would have been screened in the Dutch cities and the seating capacity of the theatres. To our surprise, a German-Swedish documentary from 1929 popped up in the Dutch top-10: Mit Sven Hedin durch Asiens Wüsten (1929). It was clear that a silent non-fiction film that was over a decade old would not be expected to rank this high. We could determine quickly that this film had indeed played for many weeks in The Hague, but only on Sunday mornings in the so-called 'Cinematografische Volksuniversiteit', an educational programme that had been screening documentaries for school children in several large Dutch cities since 1933 (Cinematografische volksuniversiteit, 1934; Film als onderwijsmiddel, 1940). The fact that this was a Sunday morning screening is mentioned in the text field in the database, but that information has proven difficult to deploy in quantitative analysis. So it is important for users of the Cinema Context dataset to appreciate the complications of the model in this respect and to correct for such aberrations in their analyses.

The week as the basic temporal unit might also create complications for programming data for the post-war period, when information with higher detail is systematically available in the sources, such as exact starting times for each screening. This is part of the broader question to what extent the current data model can accommodate more fine-grained and more recent programming data. The DIGIFIL project, funded by CLARIAH and still in progress at the time of the writing of this paper, has enabled the automated extraction of film programming data for several Dutch cities from digitized newspapers over the period $1948-1995 .{ }^{8}$ The cinema exhibition and distribution landscapes have transformed profoundly after the 196os, seeing the development of the

8 DIGIFIL is sponsored by CLARIAH, the Dutch national research infrastructure for Digital Humanities research funded by nwo (https://www.clariah.nl/), and hosted by the CREATE program at the University of Amsterdam (http://www.create.humanities.uva.nl/digifil -digital-film-listings/). 


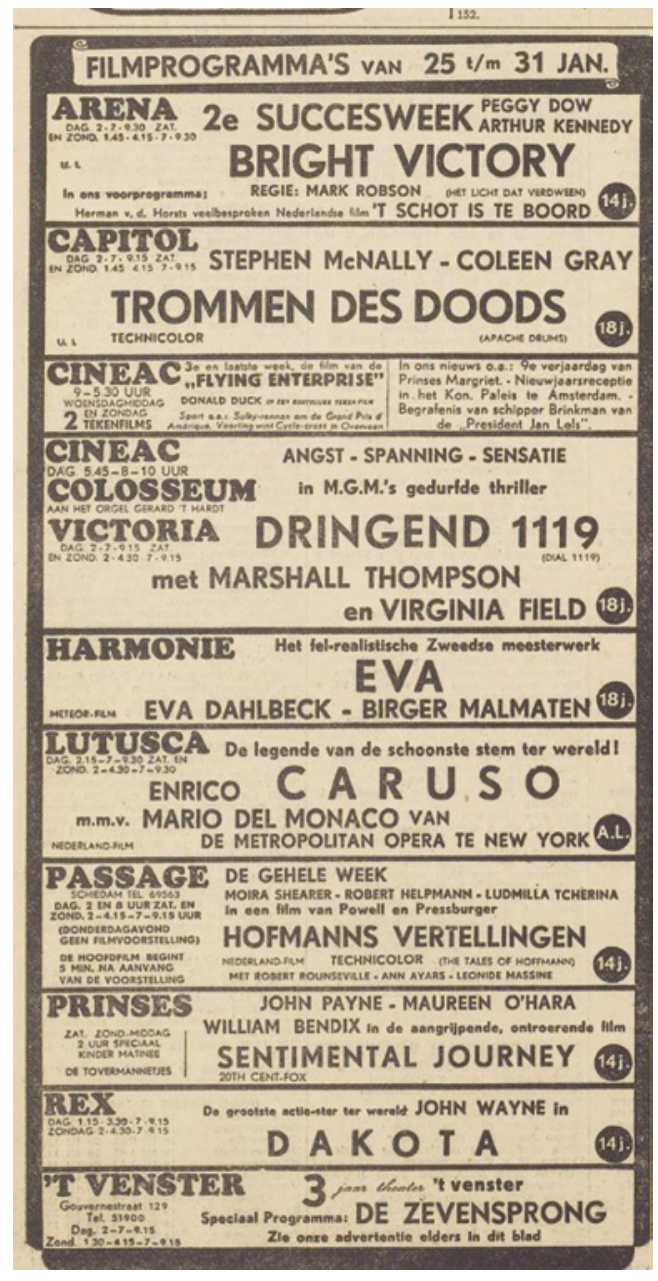

FIGURE 7 Example of a film listing in a 1950s newspaper: Het Vrije Volk, 24 January 1952. Short films and newsreels, that were often part of the cinema programme, are seldom explicitly mentioned in the listings or advertisements. If they are, such as the Dutch short ' $t$ Schot is te boord or the programme in newsreel theatre Cineac, they often are not stored in Cinema Context.

art-house and the multiplex cinema. The latter, screening multiple films simultaneously in different auditoriums in one theatre, offers a new type of programming practice. The data model does provide the option of multiple screens per cinema, but the storage of multiscreen programming in the database has not yet been put to the test. 


\section{Conclusion}

The Cinema Context database is a comprehensive, unique open dataset on the history of cinema exhibition in the Netherlands that provides unprecedented opportunities to study the history of Dutch film culture from a longitudinal and comparative perspective (Noordegraaf, Lotze, \& Boter, 2018). Its data model has set a standard for many other international projects that collect similar data on films, the places where they were shown and the people and companies that made this possible. At the same time, as we have shown in the discussion above, the choices made in collecting and modelling the data pose some restrictions that have to be carefully taken into account, in particular when performing more large-scale statistical analyses.

\section{References}

Abbott, R. (2010). Cinema context: Film in the Netherlands from 1896, an encyclopedia of film culture. Reference reviews, 24(1), 50. https://www.doi.org/10.1108/09 504121011012085 .

Allen, R. (2010). Getting to Going to the Show. New Review of Film and Television Studies, 8(3), 264-276. https://www.doi.org/10.1080/17400309.2010.499764.

Biltereyst, D., Maltby, R., \& Meers, P. (Eds.). (2011). Cinema, audiences and modernity: New perspectives on European cinema history. New York: Routledge.

Biltereyst, D., \& de Potter, P. (2018). Cinema ecosystem (CINecos): A new cinema history inspired project aiming at building an open access data platform for cinema history in Flanders and Belgium. Presentation at CREATE salon, Amsterdam (17 May 2018). http://www.create.humanities.uva.nl/events/create-salon-historical -events-data-models-2/.

Chew, C. N., \& Elhard, K. C. (2005). Cataloguing, lies, and videotape: Comparing the IMDb and the library catalogue. Cataloging \& Classification Quarterly, 41(1), 23-43. https://www.doi.org/10.1300/J104V4101_03.

Cinematografische volksuniversiteit. Eenjarig bestaan. (1934, February, 23, evening edition). Algemeen Handelsblad, p. 10. Retrieved from https://resolver.kb.nl/resolve?ur $\mathrm{n}=\mathrm{ddd}: 010662172:$ mpeg21:a0216.

Dibbets, K. (1980). Bioscoopketens in Nederland: economische concentratie en geografische spreiding van een bedrijfstak, 1928-1977 (Unpublished master thesis). Amsterdam: Universiteit van Amsterdam. https://kd.home.xs4all.nl/home/Karel\% 2oDibbets\%20-\%20Bioscoopketens\%2oin\%20Nederland\%201980.pdf.

Dibbets, K. (2010). Cinema context and the genes of film history. New Review of Film and Television Studies, 8, 331-342. https://www.doi.org/10.1080/17400309.2010 .499784 . 
Film als onderwijsmiddel. (1940, November, 23, evening edition). De Telegraaf, p. 10. Retrieved from https://resolver.kb.nl/resolve?urn=ddd:110578410:mpeg21:a0183.

Garncarz, J. (2015). Wechselnde Vorlieben. Über die Filmpräferenzen der Europäer 18961939. Frankfurt am Main and Basel: Stroemfeld.

Gennari, D., \& Sedgwick, J. (2015). Memories in context: The social and economic function of cinema in 1950s Rome. Film History. An International Journal, 27(2), 76-104.

McKernan, L. (2017, June, 1). Cinema contexts. [blog post]. Retrieved from: https:// www.lukemckernan.com/2017/06/01/cinema-contexts/.

Noordegraaf, J., Lotze, K., \& Boter, J. (2018). Writing cinema histories with digital databases: The case of Cinema Context. Tijdschrift voor mediageschiedenis, 21(2), 106126. https://www.doi.org/10.18146/2213-7653.2018.369.

Noordegraaf, J., Visser, J., Boter, J., Biltereyst, D., Meers, P., \& Kisjes, I. (2017). (Not) Going to the movies: A geospatial analysis of cinema markets in The Netherlands and Flanders (1950-1970). Digital Humanities 2017: Abstracts, 545-47. Montréal: McGill University/Université de Montréal. https://dh2017.adho.org/abstracts/586/586.pdf.

Pafort-Overduin, C. (2012). Hollandse films met een Hollands hart. Nationale identiteit en de Jordaanfilms 1934-1936 (Unpublished doctoral dissertation). Utrecht: Utrecht University.

Sedgwick, J. (2000). Popular filmgoing in 1930s Britain: A choice of pleasures. Exeter: University of Exeter Press.

Sedgwick, J., Pafort-Overduin, C., \& Boter, J. (2012). Explanations for the restrained development of the Dutch cinema market in the 1930s. Enterprise \& Society, 13(3), 634-671. https://www.doi.org/10.1017/S1467222700010880.

Thissen, J., van der Velden, A., \& van Oort, T. (2009). Over de eigenheid van de Nederlandse filmcultuur. Leidschrift, 24(3), 111-130. https://www.isgeschiedenis.nl/ longreads/over-de-eigenheid-van-de-nederlandse-filmcultuur.

van Asseldonk, N., van Mensch, P., \& van Vliet, H. (2009). Cultuur in context. Erfgoeddata in nieuwe samenhang. Amsterdam: Reinwardt Academie.

van der Velden, A., van Oort, T., \& de Jong, F. (2013). De bewogen beginjaren van de Nederlandsche Bioscoopbond, 1918-1925. Tijdschrift voor mediageschiedenis, 16(2), 23-42.

van Oort, T. (2017). Industrial organization of film exhibitors in the Low Countries: comparing the Netherlands and Belgium, 1945-1960. Historical journal of film, radio and television, 37(3), 475-498. https://www.doi.org/10.1080/01439685.2016 .1157294 .

van Oort, T. (2018). Resurrection in slow motion: the delayed restoration of the cinema exhibition industry in post-war Rotterdam (1940-65). European Review of History : Revue européenne d'histoire, 25(6), 999-1017. https://www.doi.org/10.1080/13507486 .2017.1374928.

van Oort, T., Kisjes, I., \& Vande Winkel, R. (2018). Film programming during World War II: A comparative case study into cinema exhibition in German-occupied 
Amsterdam, The Hague (NL) and Antwerp (BE). NECs Conference "Media tactics and engagements", Amsterdam, Netherlands (27-6-2018).

van Oort, T., \& Pafort-Overduin, C. (2018). New cinema history in the Low Countries and beyond: An introduction. Tijdschrift voor mediageschiedenis, 21(1), 10-18. https://www.doi.org/10.18146/2213-7653.2018.347. 